\title{
LEGITIMATE DEFENSE DIMENSIONS ACCORDING TO INTERNATIONAL LAW AGAINST ISIS
}

\author{
Sedigheh Khodadadipour ${ }^{1}$ \\ Behsar Shahani Moghaddam²
}

\begin{abstract}
Since some individuals become superior to others through possessing facilities and cruel approaches, human beings have seen torture and inhuman behaviors for ruthless intents. Over the past few years, ISIS has been the focus of global events, including the Middle East strategic area. Syria's internal armed conflict has been a context for widespread and systematic violation of human rights, humanitarian law and the growth of the activities and the formation of terrorist groups. Among these terrorist groups, there is the Islamic State of Iraq and the Syria or (ISIS) which has emerged in the Middle East since 2013 and is sponsored by some of certain Western and Arabic countries. ISIS terrorist group, by claiming the establishment of Islamic regime in Iraq, through implementing actions far from human values, has committed crimes which cause pain for the soul of every freethinking human.
\end{abstract}

Keywords: terrorism, humanitarian law, ISIS terrorist group, legitimate defense

\section{Introduction}

Crimes against humanity have attracted public attention because of its enormous outrage to the international community. Anyone who keeps track of ISIS news would understand the terrible consequences of their crimes. These crimes against humanity are considered as crimes with massive hazardous for threatening international peace and security and its impact on the international community. Hence, a large number of international documents are focused on criminalization and has considered them carefully. It is important in the case of crimes against humanity that these crimes are against human beings and violate certain general principles and cause concern of international community. These crimes

\footnotetext{
${ }^{1}$ Faculty member of International Law Department, Shiraz University, Shiraz, Iran.

${ }^{2}$ Faculty member of International Law Department, Tehran University, Tehran, Iran.
} 
have numerous examples which are mentioned in different charters and statutes. Generally, crimes against humanity are the same with war crimes. Crimes against humanity are mostly crimes that governments commit against the people of their country but war crimes usually occur with the enemy or occupied countries. ISIS is one of the most ruthless of current terrorists in Syria and Iraq. Broadness of support, financial aids and arms that are provided for opposing forces at the beginning of war in Syria have intensified the conflicts among armed groups to gain domination and increase the share of support.

\section{Formation of ISIS group}

It seems that ISIS suddenly has came out of the darkness of history and is playing a role in the center of world politics, but this is not the case, It's been a long time since its formation, ISIS is the son of Iraq war in 2003. ${ }^{3}$

In 2013, the ISIS terrorist group captured a large part of the territory of Iraq and Syria, and in the summer of 2013 occupied the city of Mosul in Iraq

\footnotetext{
${ }^{3}$ Moeinodini and Abdollahi (2015), Ten days in the Islamic state, Jürgen Todenhöfer, Koole poshti publication, p. 13.
}

and centralized its government in eastern Syria. The massive crimes against the civilian population, rapid growth in Iraq and Syria and ISIS expansionist goals proved imminent security threat to the whole region and even to the world. The formation of an international coalition against ISIS led by the United States and accompanied by some Arabic and European countries and some organizations including the European Union and NATO was in response to the terrorist acts of these groups. Practical cooperation of trans regional countries and regional countries of Saudi Arabia, United Arab Emirates, Qatar and Jordan was in the fight against ISIS. Of course, some of these countries have been involved with different levels of intervention and in various areas, from airstrike to counseling and providing war tools against ISIS.

\section{The meaning of the phrase "legitimate defense"}

Defense is an infinitive of
"repulsion" or "repulsive" (which both
have the same meaning), and in the word

Defense is an infinitive of

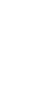


according to its subject and its uses, various meanings are given as follows: banish, distance each other, reject, pay, dispel, linger somebody's right, protect and assist. For example defend in "defending against the enemy and damage" means banish and repulse; repulse in "repulsing the word" means rejecting; and returning in the "Returning property" means repayment. Defense in the Quran means supporting and assisting someone. ${ }^{4}$ The word "legitimate" or "religious" means justifiability, being right, right incentive against the unlawful which is unfair and unjust. What the law allows is according to the religion rules and it is legal and allowable; in general it is in the meaning of compliance and religious rules. Whenever sharia or "religious rules" is used, the intention of its meaning is the revelation of Quran and Hadith which include triple elements of religion; meaning believes that science of the word is developed in it, worships that jurisprudence is written on it and morality that ethics is assigned for it.

${ }^{4}$ Mahmoudi Janaki and Sadeghi (2015), Apparent legitimate defense, Criminal law teachings, Islamic Azad University of Razavi, Number 10, P. 157.

${ }^{5}$ Jafari Langroudi (2016), Law terminology, Ganj-e Danesh publication, P. 653.

\section{4}

Sometimes the jurisprudence is practical duty rules from general application and specific will which is called sharia. The lexical and combinatorial meaning of "legitimate defense" is also nothing more than the lexical meaning of the word "defense" and the word "legitimate", that is, the repulsion of danger or aggression that is permitted by the sharia. Sometimes the term "legal defense" is used and in this case, legitimate defense is a defense based on common law. Hence, legitimate in the terminological sense of the jurists is referred to as the action in accordance with the law. ${ }^{5}$

The lawyers, for justifying legitimate defense, paid attention on two general opinions and they believe the basis of defense is one of those two; first the obligation and second to do the right or doing the task. According to the obligation, the act committed in the legitimate defense is a crime, but a crime that is not punishable. Proponents of this theory believe that an illegal invasion will eradicate freedom and that crime is subject to the voluntary disturbances. ${ }^{6}$

6 Sharifi Tarazkouhi, Chaharbakhsh and Victor Barin (2013), Preventive legitimate defense in the twenty-first century, Quarterly of public law research, Year 15, Number 40, P.13. 
To eradicate the aggression, there is no way but punishment and the result, not only prevent the aggressor from repeating the aggression but also prevent other people to not commit aggression. Also, the greatest danger of aggression is when an aggressor is left to himself, to be encouraged to repeat his aggression and others will follow his path. By banning, threatening and intimidating, Islam has provided a guarantee for security and has not even allowed the oppressed one to use rage for achieving his right. There are three types of legitimate defense in Islam: individual defense, social defense and the defense of Islam. In these cases, there is no responsibility for the terms that will be mentioned. Islam always supports the supreme human values, and in this way, human beings have been allowed to defend these values till the end. ${ }^{7}$ Therefore, the right to defend in different times has always been one of the causes for legitimacy of committing a crime. Indeed, it can be said that defending yourself derives from the nature and instinct of human. The defense exists in

\footnotetext{
${ }^{7}$ Khosravi (2007), Legitimate defense and international courts, Tehran, Faragoft publication, Number 61 .

8 Matlabi, Arayesh and Rahimi Emad (2016), Terrorism in the view of radical
}

human and animal naturally and instinctively. That is, not only human beings, but also animals in every situation where their lives and living environment are invaded, make their best efforts to escape from danger.

\section{Definition and concept of terrorism}

Terrorism is a global phenomenon and cannot be assumed that it is derived from special ethnicity, religion, country or nation. Terrorism is an old concept in the political literature. Terrorism is not a new phenomenon. Maybe it is dating to the beginning of human life. The word "terror" is derived from the Latin root of fear (ters); which means "frightening" and "panic". ${ }^{8}$ The terms of "terrorism" and "terrorist" are relatively new words.

In the supplementary attachment to the Dictionary of the French Academy of Sciences, terrorism has been meant to be a system or a horror regimen. Terror literally refers to terrible horror that results from violence, murder and bloodshed by a group, party, or

Islamic fundamentalists and political jurisprudence of Shia, a look at adductive operations, Quarterly of political studies of Islamic world, Year 6, Number 4, P.121. 
government in order to achieve political objectives, gain or retain the power ${ }^{9}$. In the literature of international organizations, this term was first used in the first article of Convention on the Prevention and Punishment of Terrorism, adopted by the League of Nations in 1937. In mentioned article, terrorism referred to criminal and misdemeanor activities that applying against a state and seeking to create panic among public, specific individual or specific group of people.

Of course, this convention due to the particular international problems of thirties and the lack of support from the governments of the time never came into executional aspect and only protected state of India approved it in January 1941. The United Nations General Assembly first considered the issue of terrorism as an independent issue in September 1972 base on initiative of Secretary-General of the time, following the events of Lod airport in Israel and the hostage taking of Israeli athletes during the 1974 Summer Olympic Games. The statement said: "Taking measures to prevent terrorism

\footnotetext{
${ }^{9}$ Hatami, B. (2016), Reading Islam from Terror and Terrorism, Survey on equivalent words, Khordname, No. 14, p. 3
}

and other forms of violence that threaten or endanger the lives of people, or endanger the fundamental freedoms, and take action to study and survey important causes of terrorism forms and acts of violence are rooted in the phenomena of poverty, frustration, oppression and disappointment. It is causing number of people by sacrificing lives of other and each other attempted to make radical changes. ${ }^{10 "}$

Definition of Terror, according to the law: Terror is any activity committed by a member or members of an organization seeking to change the republic verifiers (government), Judicial and political, social, secular and economic system that established by the contract. As well as the destruction of government's territorial integrity, the government and its people, weakening, destroying, or attacking the authority of state, threatening entity of state and society, destroying discipline, peace and security of the society. As it appears in the definition, Terrorism relatively emphasized more than Terror. Because when the concept of terrorism surveyed, is the act that its purpose requires closure

\footnotetext{
${ }^{10}$ Khosravi, A. (2008), Legitimate Defense and International Courts,t Tehran, Farragat Publications, p. 61
} 
to both truths and fears against peace and structure $^{11}$.

Terrorism includes activities such as murder, bombing, purposeless killing, aircraft hijacking and kidnapping. From this definition, some points appear that could help us to reach operational definition about the concept of terrorism. First, the motive or instigator for most of the terrorist currents and actions is to achieve political goals, sometimes ideological and religious ones. That is, terrorists want to influence the decision-making process.

In many cases, their main motive is to considering political authorities or states to the existing injustices. Hence, terrorist groups often take responsibility of their actions. This feature distinguishes terrorism from military actions and guerrilla warfare as well as mere criminal measures and organized crime ${ }^{12}$.

4. The Responsibility of Human Rights Protection

${ }^{11}$ Matlabi, M. Arayesh, H., Rahimirad, R. (2017), Terrorism in the View of Islamic Radical Islamic Fundamentalists and Shi'a Political Philosophy; by considering Istishhad operations. The Quarterly in
The protection responsibility is a commitment for protection that is violated by lack of act, abandoning actions or defective reactions. Doctrine of protection responsibility emerged as a tool to establish a proper legal balance between state's sovereignty and human rights. After the crimes committed during World War II, the doctrine of protection responsibility were proposed to make states respond the damages that inflicted to foreigners. For the people that exposed to serious human rights violations, determining the organ bound to implement of protection responsibility is essential. Given the protection responsibility, sovereignty of a state is not separable from its responsibility in protection of people who lives in its territory and cannot be merely a form of control and the World community is obligated to take appropriate measures if this responsibility is ignored or violated.

This case is not an obvious invitation to military intervention, because this intervention should always

Political Studies in the World of Islam, Vol. 6, No. 4, p. 121

${ }^{12}$ Bozorgmehri, M. (2016), Role of United Nation in fighting against Terrorism, Tehran, Imam Khomeini International University, P84 
be applied as the last solution only in exceptional circumstances ${ }^{13}$.

\section{The legitimacy of confronting ISIS}

It is certain that governments have moral responsibility against violations of fundamental human rights. Undoubtedly, if human rights systematically, grossly and widely violated in a way that affects the conscience of humanity, the silence of World community is morally and ethically not acceptable.

Whenever a state with cruel treats to its citizens, violate their basic rights in such a way that lacerate human's conscience, speak of humanitarian intervention rises. Humanitarian intervention in line with sacred purposes of international community by using legal means will have required legitimacy. International humanitarian intervention is usually defined as: Violation of a country's sovereignty does not protect fundamental human rights in the realm of its qualifications. This violation of human fundamental rights

\footnotetext{
${ }^{13}$ Karimi,S,.(2016), The way of Emergence and Formation of Terrorist Groups, Journal of Nation Research, First Edition, No.2 ,P5
}

248

often occurs by state's mistreatment or its incapability to prevent this violation. International humanitarian intervention is usually defined as a violation of state's sovereignty that is used in order to protect fundamental human rights from those who in its jurisdiction ${ }^{14}$. Justification of military humanitarian intervention based on contingent and limited interpretation of article 2, paragraph 4, of the United Nations Charter, in particular in regard with inadequacies of this organization in carrying out its task and based on the ethical and legal principles inserted in the United Nations Charter about human.

Observance of the Articles 41 and 42 principles from the United Nations Charter were legislated to prevent any abuse, overcome to national interest of states, interference legitimization and use of power for justice. The United Nations Charter based on Prohibition of the Use of Forces considered some expectation such as military action based on collective security system, the legitimate defense inserted in Article 11 of the Charter and

\footnotetext{
14 Pour Saeed, F. (2009), Revolution of Terrorism in International Relationships, Journal of Leading Studies, $12^{\text {th }}$ Year, No.4, p 146
} 
finally satisfaction with the threat and use of force on the territory of the state. It should be noted that the coalition's attacks on ISIS are not included in any of the above exceptions. Because the military intervention of the coalition, albeit based on humanitarian considerations and in line with the ideal of the United Nations Charter, is to protect humanity and clearly is in contradiction with two important principles of the charter, that the principle of use of force by states prohibition and the principle of respect for the sovereignty of states ${ }^{15}$.

Legitimate defense is a more appropriate framework for analyzing humanitarian intervention of confronting ISIS. Of course, this is not to say that legitimate defense provides an easy answer in this regard, because it is not easy to accept legitimate defense in these cases.

Coalition states also put legitimate defense is the legal base of their military action against ISIS. According to this principle, when a government is exposed to ipso facto or

\footnotetext{
${ }^{15}$ Seifzadeh, F,. Zamani, GH,. Savari, H,. Raei Dehaghi, M.(2017), Surveying Mission of Security Council in Applying Protection Responsibility Doctrine, Adoptive Legal Research, $12^{\text {th }}$ Period, No. 2, P 72
}

imminence invasion, can resort to appropriate military action to prevent the invasion. The standards of legitimate defense in the international court of justice procedure based on the interpretations of Article 51 of the United Nations Charter indicate that the existence of an initial foreign attack is on the realization of the threshold of military actions. This led to the formation of an armed attack concept, the assignment of an offensive attack on a state, government side on the attack, reaction of the state about invasion or other states that targeted to help of attacked state, the necessity and proportionality of defense, the observance of international humanitarian law standards. The obligation of advocate's report back to the Security Council, is considered as conditional and substantial provision of creating inherent right of individual and collective defense, which has not been involved in the operations and air raid of the coalition forces against the Isis group ${ }^{16}$.

Today, in the process of globalization, human rights have loses its

\footnotetext{
${ }^{16}$ Alachini, S, (2016), Protection Responsibility and Legitimation of Humanitarian Intervention, Politic Journal, 3th year, No. 12, P 51.
} 


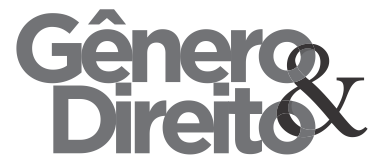

Periódico do Núcleo de Estudos e Pesquisas sobre Gênero e Direito

Centro de Ciências Jurídicas - Universidade Federal da Paraíba

V. 8 - $\mathrm{N}^{\circ} 01$ - Ano 2019

ISSN | 2179-7137 | http://periodicos.ufpb.br/ojs2/index.php/ged/index character and have become internationally recognized; on this basis, other countries cannot prevent the other countries and international organizations investigation based on human rights internal issue.

In fact, globalization of human rights has led to a new era in international policy, in which the boundary between power-based policy and norm-based policy has been faded, and governments and entities in international scene come to this conclusion that their interests are better served by respecting human rights and other components. In the era of human rights globalization, the international system does not reflect any human rights violation in the forms of crimes against humanity, war crimes and violation of the Convention on the Prohibition of Genocide, and despite the principle of non-intervention in the affairs of States and sovereignty, it starts humanitarian intervention to protect and support human rights and the supporting responsibility.

Article 51 of Charter confirms the right of individual and collective selfdefense, when an armed attack occurs against a member of United Nations. The Charter refers to this right as the inherent
250

right that previously recognized in customary international law. In addition to mentioned issues, which are mainly considered as only exceptions of the use of force by states principle, some lawyers refer to other issues such as unilateral humanitarian interventions, necessity and so on. According to Article 51 of the Charter, the condition for selfdefense is not merely due to the occurrence of the armed attack by other country, but it seems that countries are considered as the subject and victims of armed attack. Therefore, some believe that the Charter confirmed and verified the possibility of armed attack by nongovernmental. Although this important international evidence does not explicitly limit the condition of armed attack to the country, and it is possible that it carried out by non-governmental entities. There are other claims and arguments that believe self-defense can only be performed in response to an armed attack of a country.

Among the rules and standards of international law, the interpretations of the international Court of Justice can be taken into account more than all references. The arguments of this judicial institution are of great importance in Nicaragua and Israeli 
West Bank barrier. In the Nicaraguan judgment, the Court came to the conclusion that there is a general consensus and agreement in international law that armed attack does not merely involve the use of regular armed forces along international borders but it is dispatching armed platoons, irregular groups or mercenaries by the country or on the behalf of them for armed operations in other country that is so severe that it leads to armed attack such as that carried out by regular forces.

Article 51 of the Charter recognizes the existence of the inherent right for self-defense in armed attack by a country against other country, and notes that there is nothing in Article 51 of the Charter that state that self-defense is only permitted when armed attack has exclusively carried out by the government. The judges of the Court have been dealt with this issue in separate opinions. Judge Kooijmans stated in a separate judgment in Nicaragua case, because Article 51 of the Charter considered the condition for resorting to inherent right to self-defense subject to armed attack, he did not mention that armed attack should be taken on the part of the State. Therefore, the terrorist attacks create this right for the victim.

Article 51 of the Charter refers to the inherent right of self-defense against previous aggression, without mentioning that this aggression is governmental, and states that the subsequent interpretation of the Security Council in 1368 (2001) and 1703 (2001) resolutions confirms this. Therefore, if the severity and extent of attacks carried out by irregular forces are such that can be compared to attacks of regular governmental forces, it is irrational to ignore the right of self-defense for victim state, solely because the aggressor is not a governmental entity.

The supporters of the coalition against ISIS on the justification of intervention, based on the theory of responsibility to protect, argue that documents of responsibility to protect do not regard as legitimate any unilateral action by a state or a group of states, and considered it as a violation of sovereignty and territorial integrity principles, and limited it to the Security Council's resolutions, and the Security Council does not confirm the permits of armed actions for confronting ISIS. 


\section{Legal mechanism in the world}

The legal community can, by appropriate use of capabilities available in international legal system, to pathologize, improve and revise the norms. The coalition among lawyers, the utilization of legal doctrine capacities in adoption and amendment wellestablished rules and principles of international law and relating existing rules to appropriate and desired rules, are of proper results of legal community mechanism, which shows that this group of elites can create a way that is consistent to objectives of world peace, by preserving the future status in international rulemaking, and also can create the necessities of human dignity in dealing with phenomena that formal international structures are unable to perform properly against them because of political and security considerations. The lack of attention by United Nations to ISIS's threats about international peace and safety, in conditions that the actions of this group in Iraq have led to the occupation of the land, violation of human rights and humanitarian law and extensive violence against civilians, has distorted the validity and existence of international law in the public opinion of
252

the world. The pursuit of criminal law aspects of confronting terrorism and violation of human rights and humanitarian law requires high level of convergence and agreement in the international community, but it seems that it is one of the high-priority issues in providing international peace and safety and confronting ISIS's terrorist acts. It is expected that non-governmental organizations related to peace, human rights and humanitarian law, as well as elites, media, and professional associations facilitate the global perception of terrorism in the region and terrorist nature of ISIS, and to pursue civil coalition for establishing peace and confronting terrorism globally.

\section{The judgment of Hague about self- defense}

Following the military attacks of U.S on Reshadat oil platforms in October 1987 and Salman and Nasr in March 1988, the government of Islamic Republic of Iran filed a lawsuit on November 2, 1992 to Hague International Court of Justice, with a view to administer its justice, by the help of international legal authorities, during which the US military attacks on the 
platforms were considered as violation of the provisions of Treaty of Amity, Economic Relations, and Consular Rights between Iran and U.S in 1955 and international rights, and the clause 2 of Article 21 of the treaty is considered as the basis for the competence of International Court of Justice. Selfdefense is only significant against an occurred armed attack or an about to occur armed attack. Although, the U.S sought to weaken the rule stated in Clause $4 \mathrm{v}$ of Article 2 for a long times, with resorting to its lawyers' votes, by extending the scope of Article 51of the Charter. But the Court firmly resisted and bravely considered any issue based on these interpretations as disruptive of current legal order and the stability of the today international community, and also stated that they are not qualified to have any position in present international law. Paragraphs 46 to 72 of the recent judgment have analyzed the nature of the attacks to oil platforms, and the Court has attempted to evaluate the claim of the United States by examining the concept of armed attack in the Charter and interpreting Article 51 of the Charter in the light of the customary international law of resort to force.
International Court of Justice first explains the individual and collective legitimate defense and considers the alleged defense of the United States as an individual defense, since it has never claimed that it supported the neutral states that were effective in shipping in the Persian Gulf ${ }^{1}$. The United States argued that attacks against neutral ships, US-flagged ships, international regulations on deep sea mining, and the hit of warship of the country with these mines led to the formation of the concept of an armed attack mentioned in Article 51 of the Charter. The US also claimed that according to available evidence, these attacks can be attributable to Iran. So, it sought to prove the preconditions of a legitimate defense. While investigating these allegations and responses from Iran regarding the rejection of responsibility for missile attacks and mining and attributing it to Iraq, the Court concluded that there were neither armed attacks nor the attacks can be attributed to $\operatorname{Iran}^{2}$. It seems that in investigating the factors involved in the reasoning and inference of the truth, the Court did not have a logical approach. In another word, the Court first had to examine and make sure about the existence or absence of an 
armed attack within the meaning expressed in Article 51 of the Charter, and then it was possible to examine the possibility of atributing the attacks to Iran. However, the Court first reviewed US evidence of Iran's role in missile attacks and mining and rejected this attribution, then essentially concluded that there had never been an armed attack in the sense expressed in the charter ${ }^{17}$.

The judicial process of the ICJ in Nicaraguan cases, the defensive wall and armed activities in the Congo on the issue of legitimate defense against nonstate actors implies the necessity of attributing the agents' attacks to a state, and only in this case, the resort to defense by the victim government is legitimate. This is a judicial approach, while Article 51 of the Charter does not specify the source of the attack, and it can be inferred from that article that an armed attack could be attributed to nongovernmental actors. This interpretation was accepted by a majority of lawyers and in many cases, it has been supported by governments.

\footnotetext{
${ }^{17}$ Jose Delberuck, Jost, (1982). "Collective Security EPIL Vol.3. No.99

${ }^{18}$ Oil Platforms Case (Islamic Rep. of Iran v. United States of America), Jurisdictions, ICJ Rep. 1996.
}

Based on the necessity and proportionality criterion, legitimate defense must be against the real source of attack. Therefore, it is necessary to distinguish between a legitimate defense against a state and a legitimate defense against non-state actors within the territorial boundaries of a state ${ }^{18}$. If the armed attack is attributable to the host state, there will be no doubt about defending the "host" government, and if this attack is not attributable to the host government (regardless of the state's indirect responsibility or its nonresponsibility), it should be focused to legitimately defend "against actors but on the soil of the host state"19.

\section{Conclusion}

Throughout history, human beings have faced hardships such as mass murder, torture, genocide, slavery and, in general, the failure to observe their fundamental rights, which has continued in this time. Among the terrorist groups that have emerged in the Middle East in recent years, ISIS is one

\footnotetext{
${ }^{19}$ Mumtaz, Jamshid, 2011, International Law on Weapons of Mass Destruction, Publication of Salt, p. 45
} 
of the most complex groups that is still expanding despite the disagreement of the Syrian government and army and opposition in Iraq. ISIS is a gang of murders that has violated all human principles and values, and the civilians who are under the domination of this group need help because they suffer from many troubles. Islamic State of Iraq and the Levant (ISIL) terrorist group has committed numerous crimes in its occupation areas in Iraq and Syria, including the killing of civilians and militias in a heinous ways, such as decapitation, burning alive, burying alive, slavery and the sale of girls and women, torture, rape, imprisonment, genocide of Kurdish Izadis, Christians and Turkmens, plundering of public property, destruction of cities, villages and religious and historical places and so on. Therefore, according to Articles 6 and 7 of the Statute of the International Criminal Tribunal, this group has committed crimes against humanity and based on Article 8 of the Statute of the International Criminal Court, as well as the 1949 Geneva Conventions, four treaties of Geneva Conventions and 1977 Supplementary Protocols No. 1 and 2, this group has committed war crimes. Thus, it is necessary that the international community and the Iraqi government take actions and provide the necessary guarantees and measures to bring the terrorist group to trial and punish its leaders in the International Criminal Court or a special tribunal for ISIL crimes.

The inherent right to legitimate defense which is supported by the judicial procedure should allow the victim's country to resort to the right of legitimate defense against the armed attacks of non-state actors. The issue is complicated when the lack of the ability to exercise sovereignty over a part or all of its territory creates a safe haven for the attacks of non-state actors to a foreign country. According to the Court's logic in the aforementioned statements, the exercise of the right to defend against a country that does not have the ability to control its territory and where terrorists and invading groups take refuge and act against a foreign state is not acceptable. In addition, the aforementioned interpretation of article 51 deprives the invaded country of the right to legitimate defense where the non-state actor is not reliant on any other country and is not under the sovereignty of any country, such as the positioning in a free sea and outer space. According to the first point, 
Article 51 does not carry the concept of an armed attack on non-state actors when the actions of a non-state actor are not attributed to a country. Another approach is that, for the purpose of applying Article 51, it is not necessary to attribute an armed attack to a country. Therefore, the non-state actor alone has the ability to carry out an armed attack, and the moderate approach is that, in order for an armed attack to occur in accordance with Article 51, there must be a minimum criteria of attribution to the country.

\section{References}

Bozorgmehri, Majid, 2016, The role of the United Nations in the fight against terrorism, Tehran, Imam Khomeini International University Press

Mumtaz, Jamshid, 2011, International Law on weapon of mass destruction (WMD), Mizan Publishing Sq

Parsamotlagh, Shahram, 2016, Investigation on crimes against humanity and war crimes in the activities of the ISIL group in Iraq and Syria, The first national conference on modern research in the field of humanities and social studies of Iran, Tehran, Islamic
Studies and Research Center of Soroush

Hekmat Mortazavi

Poursa'ied, Farzaneh, 2009, Transformation of Terrorism in International Relations, Strategic Studies Quarterly, 12th Year, No. 4

Piri, Heidar; 2014, National Civic Interests and International Law, Majd Publications

Jafari Langroudi, Mohammad Jafar, 2017, Terminology of Law, Ganj Danesh Publication, p. 653

Hatami, Bahador, 2016, Reading of Islam from Terror and Terrorism, Analysis of equivalent vocabularies, Kheradnameh, issue 14

Khosravi, Ali Akbar, 2007, Legal

Defense and International Courts, Tehran, Faragoft Publication

Raeesi Dezaki, Leila and Kafash Nayeri, Mohammad, 2015, Globalization of Human Rights: The Principle of NonIntervention and the Syrian Crisis, Journal of Islamic Human Rights Studies, Third Year, No. 7 
Sharifi Tarazkouhi, Hossein and

Cheharbakhsh, Victor Barin, 2014,

Inhibitor Legitimate Defensive in the

Twenty-first Century, Journal of Public

Law Research, Vol. 15, No. 40

Karimi, Sahar, 2016, How the terrorist groups emerged and formed, Journal of Research in the Nations, Volume 1, Number 2

Lachinani, Sajjad, 2017, Responsibility for the Protection and Legitimacy of Humanitarian Intervention, Quarterly Journal of Policy, Vol. 3, No. 12

Mahmoudi Janaki, Firouz and Sadeghi, Azadeh, 2016, Apparent Legitimate Defense, Criminal Law Doctrines, Razavi University of Islamic Sciences, No. 10

Motallebi, Masoud; Arashi, Hassan and Rahimi Emad, Reza, 2017, Terrorism from the Viewpoint of Radical Islamic Fundamentalists and Shi'a Political Philosophy; A Look at Testimonial Missions, The Quarterly in Political Studies of the World of Islam, Vol. 6, No. 4
Moin al-Dini, Zahra and Abdollahi, Ali 2016, Day with ISIL from the Islamic State, Jürgen Tudenhaufar, Publications: Backpack Book

Saifzadeh, Farzaneh; Zamani, Qasem; Savari, Hassan and Raee Dehaghi, Massoud, 2018, Review of the Security Council mission in implementing the Doctrine of Protection Responsibility, Comparative Law Research, Volume 12, Issue 2

Savari, Hasan and Aslani, Khehbat, 2013, Armed Operation of Non-State Actors Against Countries: Doubt in the Rules Governing the Use of Force, International Law Magazine, Presidential Center for International Legal Affairs, Vol. 29, No. 46

Soltan Qais, Zahra and Marandi, Mohammad Reza, 2018, Legitimate Defense Against Terrorism, with emphasis on Syria, Second International Conference on Jurisprudence and Law, Law and Social Sciences, p. 4

Chesterman, Simon, Just War or Just Peace, Humanitarian Intervention and International Law, Oxford University Press, 2001, p. 5 
Oil Platforms Case (Islamic Rep. of

Iran v. United States of America), Jurisdictions, ICJ Rep. 1996.

Jose Delberuck, Jost, (1982). "Collective Security EPIL Vol.3. No.99

Ahmed, Dawood, (2013), "Defending Weak States against the Unable or Unwilling Doctrine of Self Defense",Journal of International Law and International Relations (Toronto). available at: http://works .bepress. com/dawood-ahmed/2

Allen, Stephen, (2010), "Harboring or Protecting? Militarized Refugees, State Responsibility, and the Evolution of Self-Defense" , Praxis the Fletcher Journal of Human Security, Vol. xxv 